\title{
Virtual Classroom Usage and User Perception for English Learning as a Second Language at Universities in Lima, Peru
}

\author{
https://doi.org/10.3991/ijet.v16i08.19221 \\ Carlos Celso La Torre Castillo \\ Universidad Científica del Sur, Lima, Peru \\ 100065377 @cientifica.edu.pe
}

\begin{abstract}
A more extensive use of virtual tools in teaching-learning processes needs a professors' and students' proactive attitude, positive experiences, and improvement in their implementation. A cross-sectional study was carried out to know the perceptions of private university students from Lima on the use of the necessary elements for an English language virtual classroom. The sample was composed of 150 accounting students from five universities, whose perceptions on virtual classroom elements were assessed and compared to their previous experiences. Most students were in favor of using the virtual classroom and its different elements, and those who had a previous experience with virtual classrooms were more in favor of using reminders, chats, forums, e-mails and online exercises $(p<0,05)$. In sum, most students were in favor of using the virtual classroom and having a previous experience favors a more positive perception towards online learning tools.
\end{abstract}

Keywords - Learning, virtual classroom, virtual education, elements, virtual tools, English, universities

\section{Introduction}

Virtual education provides a knowledge transfer opportunity for students by means of teaching-learning processes supported on various strategies that encourage studying, so that students can learn or teach through this learning system.

The virtual classroom is one of the student motivation strategies that supports on technologies used in educational environments through various e-learning platforms [1]. E-learning is getting more popular in higher education [2] with ICT applications that offer many learning options for students [3] and foster self-managed learning by giving students more access to virtual environments [4]. Finally, when students apply e-learning, they can fully manage their pace of study, since they no longer need to attend face-to-face lectures on campus [5].

The use of the e-learning system creates innovative processes that fit the needs of professors and students, key players in the teaching-learning process. Mahande and 
Jasruddin define e-learning as a dynamic learning environment [6]. In developed countries, the use of e-learning has provided many service qualities attributes [7].

On the other side, e-learning systems have recently been introduced in schools, corporations and sector organizations to increase learning efficiency and overcome the disadvantages of regular learning [8]. In this study, the implementation of online English classes in Peru focuses on the use of virtual classrooms by students that are proficient in English or have studied English to gain a competitive advantage in the work market.

In this competitive, globalized world, the use of virtual classrooms for English learning offers teenagers the necessary tools or elements to excel and reach high professional levels. Using these tools generates gradual changes and has a great impact in virtual education [9].

Old elements used in virtual learning such as hypertexts, online interactive multimedia, teleconference, videoconference and satellite TV would affect the acceptability of students, who favour the use of virtual classroom elements since their digital abilities are more proficient.

In English learning, the perception on the use of virtual classroom elements is important for university students since it will help them improve their low level of English proficiency, obtain their professional degree (legal requirement pursuant to University Law 30220) and access better information sources for their professional education.

Peruvian students from 18 to 25 speak English better, in a more fluent manner. The English language teaching process will favour teaching grammar structures and text translation to students [10].

After learning English for five years, male students acquire limited knowledge and when they enter the university, they must relearn the language [11]. According to EPI, important data indicate that female language proficiency is higher $(53.34 \%)$, whereas men show a lower ability to learn English (47.29\%).

Nowadays in this new reality in Peru, English teaching institutes such as ICPNA, Británico, Idiomas Católica and Euroidiomas have been implementing e-learning systems and virtual classrooms to further English studies. The virtual classrooms they use contain all types of educational elements such as educational games, chats, audios and videos to improve their students' English language proficiency. Furthermore, there is a wide range of tools available to facilitate English learning [12], thus being a different way to improve their communication skills [13].

The purpose of this study is to know the perception of students from private universities of Lima on the use of the elements that a virtual classroom must contain for English learning.

\section{$2 \quad$ Method}

A cross-sectional descriptive study was conducted in the second semester of the year 2016. This project was approved by the Graduate School of Universidad Cientifica del Sur.

Students registered in the last terms of the accounting programs from five private universities of Lima (Universidad de Lima, Pontificia Universidad Católica del Perú, 
Universidad del Pacífico, Universidad Peruana de Ciencias Aplicadas, and Universidad San Martín de Porres) were included in this study. A non-probability convenience sampling was applied, and students were selected from their university campuses with a previous verbal consent. The study excluded those students who refused to be part of the study and those who did not fill out the survey. A total of 30 people was selected from each university, a total sample of 150 participants.

A 12-question instrument was developed to measure the perception on the use of virtual classroom elements for English learning. A 5-point Likert scale was applied to measure their level of agreement (ranging from strongly agree to strongly disagree), whose logical validity was verified by three experts. Then, a pilot with 30 undergraduate students was conducted to verify comprehension. A Cronbach's alpha was found to be 0.92 in the study population.

These variables were categorized as "in favour," if students agree or strongly agree with virtual classroom elements for English learning. Additionally, other variables were considered: demographic variables, if students had previous experience with online courses or if students consider that the content of an English course could be included in the virtual classroom.

The data base was exported into the statistical software STATA (v. 14.0). Descriptive measures were calculated and the relation between the perceptions on the use of virtual classrooms for English learning and the previous experience with virtual classrooms was assessed using the Chi-square test and considering $\mathrm{p}<0.05$ as a statistically significant result.

\section{$3 \quad$ Results}

From the 150 student volunteers from five universities located in Lima Metropolitana, Table 1 shows that they belong to 20-24 age range and were then registered in the last terms of their programs. In addition, they all had an A1 English level, i.e., they have a vast knowledge of the English language. 
Table 1. Carachteristics of participants

\begin{tabular}{|l|l|l|}
\hline & $\mathrm{n}$ & $(\%)$ \\
\hline Age, median (DS) & 22 & $(1,6)$ \\
\hline Gender & & \\
\hline Male & 78 & 52 \\
\hline Female & 72 & 48 \\
\hline University & & \\
\hline Pontificia Universidad Católica del Perú & 32 & 21.3 \\
\hline Universidad Peruana de Ciencias Aplicadas & 30 & 20 \\
\hline Universidad de Lima & 30 & 20 \\
\hline Universidad del Pacifico & 29 & 19.3 \\
\hline Universidad San Martin de Porres & 29 & 19.3 \\
\hline Term & & \\
\hline 7th & 30 & 20 \\
\hline 8th & 50 & 33.3 \\
\hline 9th & 53 & 35.3 \\
\hline 10th & 17 & 11.3 \\
\hline English Proficiency Level & & \\
\hline Basic (A1) & 150 & $100 \%$ \\
\hline Previous experience with online classes & & \\
\hline Yes & 86 & 57.3 \\
\hline No & 64 & 42.7 \\
\hline
\end{tabular}

Regarding the use of virtual classroom elements, Fig. 1 shows that participants "strongly agree" with the use of virtual classroom elements such as the different access devices and videos. Additionally, participants "agree" with the use of all these elements, especially audios, task reminders, interactive games, cloud storage, practical exercises, interactive forums, online chat, and e-mail.

Most students (57.3\%) were in favour that the English course content must be uploaded to the virtual classroom to improve their knowledge of the English language.

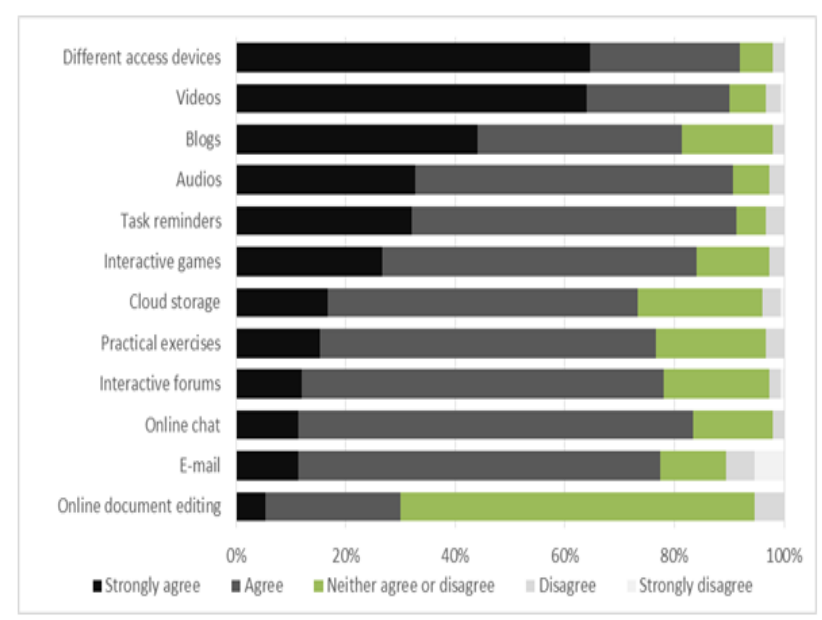

Fig. 1. Students' perceptions on the use of virtual classroom elements for English courses 
Table 2. Difference in the perception on the use of virtual classroom elements for English learning according to the previous experience with virtual classrooms

\begin{tabular}{|c|c|c|c|c|c|c|c|}
\hline \multirow[t]{2}{*}{ Use of } & \multicolumn{2}{|c|}{ In favor } & \multicolumn{2}{|c|}{$\begin{array}{l}\text { With previous } \\
\text { experience }\end{array}$} & \multicolumn{2}{|c|}{$\begin{array}{l}\text { Without previous } \\
\text { experience }\end{array}$} & \multirow[t]{2}{*}{$p$} \\
\hline & $\mathrm{n}$ & $(\%)$ & $\mathrm{n}$ & $(\%)$ & $\mathrm{n}$ & $(\%)$ & \\
\hline $\begin{array}{l}\text { Different access } \\
\text { devices }\end{array}$ & 138 & $(92,0)$ & 82 & $(95,4)$ & 56 & $(87,5)$ & 0,080 \\
\hline Task reminders & 137 & $(91,3)$ & 83 & $(96,5)$ & 54 & $(84,4)$ & 0,016 \\
\hline Audios & 136 & $(90,7)$ & 79 & $(91,9)$ & 57 & $(89,1)$ & 0,560 \\
\hline Videos & 135 & $(90,0)$ & 80 & $(93,0)$ & 55 & $(85,9)$ & 0,153 \\
\hline Interactive games & 126 & $(84,0)$ & 72 & $(83,7)$ & 54 & $(84,4)$ & 0,914 \\
\hline Online chat & 125 & $(83,3)$ & 77 & $(89,5)$ & 49 & $(75,0)$ & 0,018 \\
\hline Blogs & 122 & $(81,3)$ & 71 & $(82,6)$ & 51 & $(79,7)$ & 0,655 \\
\hline Interactive forums & 117 & $(78,0)$ & 74 & $(86,1)$ & 43 & $(67,2)$ & 0,006 \\
\hline E-mail & 116 & $(77,3)$ & 72 & $(83,7)$ & 44 & $(68,8)$ & 0,030 \\
\hline Practical exercises & 115 & $(76,7)$ & 71 & $(82,6)$ & 44 & $(68,8)$ & 0,048 \\
\hline Cloud storage & 110 & $(73,3)$ & 66 & $(76,7)$ & 44 & $(68,8)$ & 0,273 \\
\hline DocumentEditing & 45 & $(30,0)$ & 26 & $(30,2)$ & 19 & $(29,7)$ & 0,943 \\
\hline
\end{tabular}

Regarding the use of virtual classroom elements, Table 2 shows that students are in favour of 11 out of the 12 items evaluated, being the only exception document editing. On the other side, people with previous experience using the virtual classroom for online classes had a better perception towards five elements than those that did not have a previous experience: task reminder, online chat, interactive forums, e-mail for access, and online practical exercise $(\mathrm{p}<0.05)$.

\section{Discussion}

According to the results obtained, the study concluded that $57.3 \%(<60 \%)$ of students were in favour to include the English course content into the virtual classroom to improve their knowledge of the English language. This percentage is higher in the case of students with previous experience using virtual classrooms. Therefore, we can say that virtual classrooms can spark the interest of students in learning, by developing creative thinking when they use them.

A similar result can be found in Guacho's study [14], where students stated that the use of a virtual classroom would improve their knowledge by making them active participants in the learning process, and $33 \%$ of these students had already used virtual classrooms. In contrast, Ramos' study [15] indicated that $44.88 \%$ of the population surveyed considers virtual classroom of little use in the learning process.

On the other side, people with previous experience using the virtual classroom for online classes had a better perception towards five (5) elements than those that did not have a previous experience: task reminder, online chat, interactive forums, e- mail for access, and online practical exercise $(\mathrm{p}<0.05)$. Consistent with our findings, Castillo [16] highlighted the importance to exploit technological tools: chats, videos, and forums. 
Therefore, the use of technological tools helps us identify students' needs in terms of virtual classroom requirements, with the purpose of making the most of these technologies and be at the forefront of change.

According to the results obtained, there was an increase in students' level of knowledge consistent with the results reported by Abreu Peralta [17] that show that high school students' level of knowledge, practice and attitudes improved with the incorporation of ICTs. Similar results were also found by Martin [18], who discovered that students were more interested in participating in the English learning process when it involved the use of a virtual classroom. On the contrary, a study conducted by Mejía [19] demonstrated that $40 \%$ of English students never used the forum or chats to communicate. In consequence, what has been described here serves to benefit students from a passive role to an active role to strengthen English learning by using virtual classroom elements.

In conclusion, we can say that most people have already had a previous experience using virtual classrooms, which changes the perception they have on the use of virtual classrooms for English learning. Now there are many institutions that use this type of technology for their classes.

Virtual classrooms contain multiple tools such as discussion section, conferences, forums, reading lessons [20]. The different virtual classrooms have different elements and characteristics in terms of space, time, resources, communication, and interaction.

The results obtained are related to the current pandemic situation. It helps understand what may happen during and after this situation. It is important to understand that we are forced to be more open than ever to face the changes and challenges posed by the Covid-19 pandemic, which caused universities to close [21] and compelled them to massively use virtual classrooms.

Then, the suspension of face-to-face classes was decreed in the education industry, and professors started delivering online classes by bringing and/or adapting their faceto-face lectures into this environment. Online classes are teaching models that are useful for providing students with feedback to improve their assignments and evaluations [22] supported on e-learning as a tool available in the online environment [23].

The Covid-19 pandemic in Peru has forced many public and private educational institutions to deliver online classes instead of face-to-face sessions to prevent the spread of the disease among students. In our research, where most students have had a previous experience with virtual classrooms, it is concluded that most of them favor the use of this virtual tool in this context even though they were forced to adapt to this new study mode.

Therefore, this pandemic has given everyone the opportunity to have an entire virtual education experience, gaining more knowledge about this tool and improving the general willingness to use audios, task reminders, interactive games, cloud storage practical exercises, interactive forums, online chats and e-mail contained in the virtual classrooms. 


\section{$5 \quad$ Study Limitations}

This is not a probability study with students from Lima; therefore, it cannot be extrapolated to all university students. In fact, we selected students from private universities that have a better access to internet and technologies than public universities.

The study started before the Covid-19 pandemic and shows a previous panorama, where students were not that exposed to virtual learning tools. The use of virtual classroom elements helped students to resume their English classes.

\section{Conclusion}

Most students agree to use virtual classroom elements for English learning, especially in this global pandemic due to the Covid-19 virus. Using virtual classrooms is now more frequent to take care and protect students from this disease.

Most students have had a previous experience with virtual classrooms and agree to use different elements from these online platforms. Students had a more positive perception towards the following elements: task reminder, online chat, interactive forums, e-mail for access, online practical exercises.

\section{$7 \quad$ References}

[1] Rodrigues, W., Zárate, L. E., \& Isotani, S., (2018). Educational Data Mining: A review of evaluation process in the e-learning. Journal \& Books ScienceDirect. Volume 35, issue 6, pages 1701-1717. https://doi.org/10.1016/j.tele.2018.04.015

[2] Tsai, C., Shen, P., \& Chiang, Y., (2013). The application of mobile technology in e-learning and online education environments: A review of publications in SSCI-indexed journals from 2003 to 2012. International Journal of Enterprise Information Systems, 9(4), 85-98. https://doi.org/10.4018/ijeis.2013100106

[3] Sarabadani, J., Jafarzadeh, H., \& ShamiZanjani, M. (2017). Towards understanding the determinants of employees' e-learning adoption in workplace: A unified theory of acceptance and use of technology (UTAUT) view. International Journal of Enterprise Information Systems, 13(1), 38-49. https://doi.org/10.4018/ijeis.2017010103

[4] Bhuasiri, W., Xaymoungkhoun, O., Zo, H., Rho, J. J., \& Ciganek, A. P. (2012). Critical success factors for e-learning in developing countries: A comparative analysis between ICT experts and faculty. Computers \& Education, 58(2), 843-855. https://doi.org/10.1016/j. compedu.2011.10.010

[5] Harrati, N., Bouchrika, I., Tari, A., Ladjailia, A., (2016) Exploring user satisfaction for elearning systems via usage-based metrics and system usability scale analysis, Computers in Human Behavior. Elsevier Ltd, 61, pp. 463-471. https://doi.org/10.1016/j.chb.2016.03.051

[6] Cacheiro, M., García, F., \& Moreno, A., (2015). Las TIC en los programas de Formación Profesional Básica en Ceuta. Revista de Innovación Educativa, vol 7, num 2.

[7] Althunibat, A., (2015). Determining the factors influencing students intention to use mlearning in Jordan higher education, Comput. Hum. Behav., vol. 52, pp. 65-71. https:// doi.org/10.1016/j.chb.2015.05.046 
[8] Torres, L., Vásquez, E., Velásquez, T., (2016). Diagnóstico de la metodología de la enseñanza del idioma inglés en el nivel secundario en las instituciones educativas públicas en el distrito de Trujillo. Universidad Nacional de Trujillo. https://doi.org/10.21895/incres.2016.v7n2.10

[9] Zierer, C., (2015). La situación de la enseñanza de idiomas en el Perú. Revista de Centro Virtual Cervantes, Boletín AEPE No 25.

[10] Rodríguez, P., (2016). Uso pedagógico de la Plataforma Virtual Chamilo para incentivar la producción escrita en el proceso de enseñanza de inglés en una universidad privada de Lima. Pontificia Universidad Católica del Perú. https://doi.org/10.20511/pyr2013.v1n2.49

[11] De La Vega Polanco, M., (2019). Aprendizaje del idioma inglés aplicando metodología Blended en estudiantes de la I.E Las Capullanas, Sullana-Piura. Universidad Nacional Federico Villareal. https://doi.org/10.36955/riulcb.2019v6n1.002

[12] Nguyen, H.-T.T., (2020). Communication skills and reflection practice in smart English teaching and learning environment a case study. International Journal of Emerging Technologies in Learning 15(17), pp. 221-237. https://doi.org/10.3991/ijet.v15i17.15235

[13] Dursun, T., Oskaybas, K., \& Gokmen, C., (2014). Perceived quality of distance education from the user perspective. Contemporary Educational Technology, 5(2), 121-145. https:// doi.org/10.30935/cedtech/6120

[14] Guacho, G., \& Guilcapi D., (2015). Análisis, diseño e implementación de aulas virtuales como complemento para el proceso de enseñanza-aprendizaje en las asignaturas de inglés, español y Kichwa para el tercer año de bachillerato del instituto superior pedagógico intercultural bilingüe Jaim. Universidad Nacional de Chimborazo. https://doi.org/10.29197/ cpu.n31.v16.2019.03

[15] Ramos, M., (2014). Percepción de los estudiantes universitarios sobre la utilidad del aula virtual para el aprendizaje. PAIDEIA XXI, 4(5), 82-94. https://doi.org/10.31381/paideia. $\underline{\mathrm{v} 4 \mathrm{i} 5.910}$

[16] Castillo, H., (2015) Implementación de la plataforma Chamilo LMS como apoyo a la mejora de la Comprensión Lectora en el proceso de aprendizaje del curso de Comunicación del 3er año de secundaria en la IEP Niño Jesús de Praga, Castilla Piura. Universidad Cesar Vallejo. https://doi.org/10.12795/9788447221912.053

[17] Peralta, A., \& Carrillo, E., (2015). Uso de estrategias didácticas implementando las TIC, en educación para la sexualidad en adolescentes de 14 a 16 años en instituciones educativas oficiales de Piedecuesta y Lebrija. Universidad Autónoma de Bucaramanga. https:// doi.org/10.5965/1984723817332016135

[18] Martin, C., (2012). Explorando nuevos recursos virtuales con alumnos de Informática: aplicaciones educativas a las clases de inglés. Revista Iberoamericana de Educación. TE\&ET n ${ }^{\circ}$ 8, pp. 34-44.

[19] Mejia, P., \& Mejia, P. (2013). Uso de las aulas virtuales en el desarrollo de la comprensión oral del idioma inglés para los estudiantes del cuarto nivel de inglés del centro universitario de idiomas de la Universidad Central del Ecuador. Universidad Central de Ecuador. https://doi.org/10.31235/osf.io/mzynx

[20] Garcia, F., Corell, A., Abella, V., \& Grande, M., (2020). Online Assessment in Higher Education in the Time of COVID-19. Journal Education in The Knowlwdge Society 21 article 12, pp. 12-26.

[21] Mohamed, D., (2020). The Contemporary Vision of Universal Strategic Planning for Facing (COVID-19) Crisis in the Field of Higher Education Virtual Learning \& Training. European Journal of Education. vol. 3, pp. 151-164. 
[22] Obonya, J., Kadlečík, M., (2020). Assessing the intensity of the usability of the course content within the virtual learning environment. International Journal of Emerging Technologies in Learning 15(17), pp. 165-180. https://doi.org/10.3991/ijet.v15i17.13715

[23] Al-Azawei, A., Al-Masoudy, M.A.A., (2020). Predicting learners' performance in Virtual Learning Environment (VLE) based on demographic, behavioural and engagement antecedents. International Journal of Emerging Technologies in Learning 15(9), pp. 60-75. https://doi.org/10.3991/ijet.v15i09.12691

\section{Author}

Carlos Celso La Torre Castillo is a systems engineer with more than 10 years of professional and work experience in prestigious public and private institutions.

Article submitted 2020-10-14. Resubmitted 2020-12-01. Final acceptance 2020-12-05. Final version published as submitted by the authors. 